\title{
Volumetric MR-guided high-intensity focused ultrasound ablation to treat uterine fibroids through the abdominal scars
}

\author{
Zhu Ying ${ }^{1 *}$, Bilgin Keserci ${ }^{2}$, Xuedong Yang ${ }^{1}$, Xiaoying Wang ${ }^{1}$ \\ From Current and Future Applications of Focused Ultrasound 2014. 4th International Symposium \\ Washington, D.C, USA. 12-16 October 2014
}

\section{Background/introduction}

Magnetic resonance (MR)-guided high intensity focused ultrasound (HIFU) is an emerging therapy technique using focused ultrasound to heat and coagulate tissue deep within the body, without damaging intervening tissue. However, massive abdominal scar tissues were considered as relative contraindications as the higher energy absorption of the scar tissue might result in skin heating at the site of the scar [1]. Obstruction in the near-field of the focused ultrasound beam, such as indeed extensive abdominal wall scar tissue could lead to increased absorption of acoustic energy and skin burns [2]. In some conditions, it is possible avoid the ultrasound beam passing through the scar tissue by tilting the transducer or filling the bladder [3]. Yoon et al. started to use the scar patch to blocking the beam, which would reduce the risk of skin burn and enlarge indications with point by point technique [4]. In our preliminary study, we used the scar patch in three patients, one with transverse incision, and the other two with longitudinal incision using volumetric technique [5].

\section{Methods}

MR-HIFU treatment was performed by stepping through several treatment cell ablations with cooling times between each sonication using a Philips Healthcare clinical HIFU platform integrated into a $3 \mathrm{~T}$ Philips Achieva MR scanner. The scar patch used in this study was made of isolation polyethylene foam (1.5-mm-thick Cell-Aire; Sealed Air, Elmwood Park, New Jersey) covered with a double-coated medical tape (9889; 3M, St. Paul, Minnesota). FFE was performed for the scar and scar patch

${ }^{1}$ Peking University First Hospital, Beijing, China

Full list of author information is available at the end of the article with the following imaging parameters: coronal, TR/TE 3.4/1.74 ms, FOV $200 \mathrm{~mm}$, slices 29 thickness $1.0 \mathrm{~mm}$, Voxel size $1.5 \times 1.5 \times 1.0 \mathrm{~mm} 3$, TA $1 \mathrm{~min} 18 \mathrm{sec}$. 3D T2WI was performed for treatment planning: sagittal, FOV $241 \mathrm{~mm}$, TR/TE 1550/150 ms, thickness $1.6 \mathrm{~mm}$, slice 150 . Voxel size $1.0 \times 1.0 \times 1.6 \mathrm{~mm} 3$, TA $5 \mathrm{~min}$ $56 \mathrm{sec}$. The MR sequence used for temperature mapping is an RF-spoiled segmented Echo Planar Imaging sequence $(E P I-$ factor $=11$, repetition time $T R=37 \mathrm{~ms}$, echo time $\mathrm{TE}=19.5 \mathrm{~ms}$, 121-binomial water selective excitation). Immediately following the treatment, Fatsaturated T1-weighted THRIVE sequence used to for evaluate the volume of the fibroids ((turbo field echo (TFE), 17 axial slices; TR/TE: $500 / 10 \mathrm{~ms}$; slice thickness: $5 \mathrm{~mm}$ with $1 \mathrm{~mm}$ gap; FOV, $240 \times 240 \mathrm{~mm}$; matrix, $320 \times 250$; flip angle: 90 degree).

\section{Results and conclusions}

In the first case, a 41-year-old woman with transverse incision had a single intramural type 1 fibroid. The volume of the fibroid was $111.98 \mathrm{ml}$. The treatment time was $165 \mathrm{~min} 17 \mathrm{sec}$. Following delivery of multiple sonications to the treatment area, The NPV immediately after treatment was $52.35 \%$. No abnormal areas of enhancement within the subcutaneous tissue or the regions of the scar were identified. In the second case, a 49-year-old woman with a longitudinal incision had multiple type 1 fibroids. The target fibroid was located in the anterior wall. The scar patch was in the middle sagittal plane while the fibroid was located left of the uterus. The volume of the fibroid was $71.17 \mathrm{ml}$. The treatment time was $112 \mathrm{~min} 1 \mathrm{sec}$. The NPV immediately after treatment was $50.32 \%$. Skin heating was mild, and no severe advent event occurred. In the last case, a 43year-old woman with a longitudinal incision also had 
multiple type 1 fibroids. The volume of the fibroid was $100.90 \mathrm{ml}$. The fibroid was in the left of the uterus, almost beyond the scar. The treatment time was $100 \mathrm{~min} 44 \mathrm{sec}$. The NPV immediately after treatment was $73.21 \%$. Mild skin heating was complained, without severe advent events. The scar patch could effectively avoid heating around the scar tissue (both horizontal and longitudinal), and expand the indication of MR-HIFU treatment of uterine fibroids with volumetric technique.

Written informed consent was obtained from the patient(s) for publication of this abstract and any accompanying images.

\section{Authors' details}

${ }^{1}$ Peking University First Hospital, Beijing, China. ${ }^{2}$ Philips Healthcare, Seoul, Republic of Korea.

Published: 30 June 2015

\section{References}

1. Yoon $\mathrm{S}$, et al: Patient selection guidelines in MR-guided focused ultrasound surery of uterine fibroids: a pictorial guide to relevant findings in screening pelvic MRI. Eur Radiolo 2008, 18(12):2997-3006.

2. Leon-Villapalos, et al: Full thickness abdominal burn following magnetic resonance guided focused ultrasound therapy. Burns 2005, 31(8):1054-5.

3. Zaher $\mathrm{S}$, et al: A novel method to aid in the visualization and treatment of uterine fibroids with MRgFUS in patients with abdominal scars. Eur $J$ Radiol 2010, 76(2):269-73.

4. Yoon S.W., et al: Mitigation of abdominal scars during MR-guided focused ultrasound treatment of uterine leiomyomas with the use of an energy-blocking scar patch. J Vasc Interv Radiol 2011, 22(12):1747-50.

5. Kohler $\mathrm{MO}$, et al: Volumetric HIFU ablation under 3D guidance of rapid MARI thermometry. Med Phys 2009, 36(8):3521-3535.

doi:10.1186/2050-5736-3-S1-P88

Cite this article as: Ying et al:: Volumetric MR-guided high-intensity focused ultrasound ablation to treat uterine fibroids through the abdominal scars. Journal of Therapeutic Ultrasound 2015 3(Suppl 1):P88.

\section{Submit your next manuscript to BioMed Central} and take full advantage of:

- Convenient online submission

- Thorough peer review

- No space constraints or color figure charges

- Immediate publication on acceptance

- Inclusion in PubMed, CAS, Scopus and Google Scholar

- Research which is freely available for redistribution

Submit your manuscript at www.biomedcentral com/submit
C Biomed Central 